\title{
Effect of molar weight of gelatin in the coating of alginate microparticles
}

\author{
Joelma Correia Beraldo ${ }^{1}$ (D), Gislaine Ferreira Nogueira² ${ }^{\text {DD }}$, Ana Silvia Prata ${ }^{3 *}$ (D) and \\ Carlos Raimundo Ferreira Grosso ${ }^{1}$ (D)
}

\author{
${ }^{1}$ Departamento de Alimentos e Nutrição, Faculdade de Engenharia de Alimentos, Universidade Estadual \\ de Campinas - UNICAMP, Campinas, SP, Brasil \\ ${ }^{2}$ Universidade do Estado de Minas Gerais - UEMG, Passos, MG, Brasil \\ ${ }^{3}$ Departamento de Engenharia de Alimentos, Faculdade de Engenharia de Alimentos, Universidade \\ Estadual de Campinas - UNICAMP, Campinas, SP, Brasil \\ *asprata@unicamp.br
}

\begin{abstract}
The protein adsorption on the porous alginate microparticles was evaluated in regards to the coating ability and this protective effect during gastrointestinal assay. The coating was performed at suitable $\mathrm{pH}$ for optimized electrostatic interaction between protein and alginate. Concentrations of gelatin (HGE) and their hydrolysates (Collagel® (MGE) $(>10 \mathrm{kDa})$ and Fortigel $\left.{ }^{\circledR}(\mathrm{LGE})(3 \mathrm{kDa})\right)$ from 1 to $10 \%(\mathrm{w} / \mathrm{w})$ were tested. Higher protein adsorption was observed in the highest concentration of protein in solution and the amount adsorbed was inversely proportional to the degree of hydrolysis with 47.3, 41.4 and $29.3 \%$ of protein adsorbed when HGE, MGE and LGE were used, respectively. The particles that showed higher protein adsorption were submitted to gastrointestinal in vitro assay. In gastric simulation, 39.1, 41.8 and 49.0\% of protein from HGE, MGE and LGE were solubilized while 81.3, 61.5 and 95.2\% were solubilized after $5 \mathrm{~h}$ under enteric conditions.
\end{abstract}

Keywords: microencapsulation, ionic gelation, electrostatic interaction, layer-by-layer, protein adsorption.

How to cite: Beraldo, J. C., Nogueira, G. F., Prata, A. S., \& Grosso, C. R. F. (2021). Effect of molar weight of gelatin in the coating of alginate microparticles. Polimeros: Ciência e Tecnologia, 31(2), e2021018. https://doi.org/10.1590/01041428.20210027

\section{Introduction}

Ionic gelation (IGEL) is one of the most used techniques for encapsulation of sensitive, bioactive, and functional compounds $^{[1-4]}$, cells and probiotic bacteria ${ }^{[5,6]}$, due to the mild conditions employed, ie, absence of heating or organic solvents and moderated stirring rate conditions ${ }^{[1]}$. The interactions of the anionic charge of the polysaccharide $\left(\mathrm{COO}^{-}\right)$with cationic ions lead to a tridimensional gel network ${ }^{[7]}$ which is highly porous ${ }^{[6]}$ and undesirable when it is expected a controlled release. There are many examples in the literature reporting on the rapid release of bioactive compounds from gelled microparticle after simulated gastroenteric assays ${ }^{[2,3,8]}$. Layer-by-layer protein deposition onto gelled particles has been successfully employed aiming to increase the resistance in gastric conditions ${ }^{[8-10]}$ or to reduce the losses of hydrophilic compounds to the product ${ }^{[1]}$.

Gelatin (HGE) has a positive charge below its isoelectric point (IEP) and can interact with alginate, an anionic polysaccharide, above its $\mathrm{pKa}$ values ${ }^{[11]}$. It is obtained from collagen through acid (type A, IEP, 7.0-9.0) or alkaline hydrolysis (type B, IEP, 4.6-5.2) ${ }^{[12]}$ and its molecular weight (MW) varies from 300-200.000 Da depending on the raw material and the process conditions ${ }^{[13]}$. Globular proteins explored for layer-by-layer deposition ${ }^{[10,14]}$ present topological

limitations which prevent their charged groups to optimally contact the rigid anionic polysaccharide chains ${ }^{[15]}$. The hypothesis is that unfolded protein structures, such as HGE, can form a maximum number of contacts with the charged polysaccharide chain, covering more efficiently particles produced by IGEL. Moreover, the average molecular weight of protein hydrolysates is one of the most important factors which determines their biological properties. The reduced molecular weight in the peptide fractions also better exposure of the amino acid residues, being suggested as a factor that facilitate the interaction with other polymers ${ }^{[16]}$. However, in the context of layer coating formation, the changes in the structures may reduce the contribution between proteinprotein adsorption, changing the organization of the layer formed ${ }^{[17]}$ and resulting in differences of protein adsorption. Information published on electrostatic interaction (EI) as a consequence of molecular weights are not prevalent. In this work, the effect of the molar weight of gelatin (HGE) was evaluated in regards to the protein adsorption on the porous alginate microparticles and to their protective effect during gastrointestinal assay. The conditions for EI between type A HGE and two commercial hydrolysates of collagen, Collagel ${ }^{\circledR}(\mathrm{MGE},>10 \mathrm{kDa})$ and Fortigel ${ }^{\circledR}(\mathrm{LGE}, 3 \mathrm{kDa})$ 
were initially established. Under optimized charge conditions, protein concentrations varying from 1 to $10 \%(\mathrm{w} / \mathrm{w})$ were tested to perform the coating. The coated microparticles were characterized with respect to morphology, average size, adsorbed protein and moisture contents. The microparticles that showed higher protein adsorption were evaluated for resistance to gastrointestinal conditions in vitro (GIA) by quantifying the solubilized protein content and following their morphology.

\section{Materials and Methods}

\subsection{Materials}

Sodium alginate (SA) (FMC Biopolymer, lot G470020,SP, Brazil, medium viscosity (200 - $400 \mathrm{mPa} . \mathrm{s})$, and mannuronic to guluronic acid ratio $\geq 1.53$ ); type $\mathrm{A}-$ gelatin (HGE) containing $90.15 \pm 1.28 \%$ of proteins ${ }^{[18]}$ (Gelita, lot 21502 P-04, SP, Brazil); Collagel ${ }^{\circ}$ (MGE) containing 96.72 $\pm 0.11 \%{ }^{[18]}$ of proteins (MW $>10 \mathrm{kDa}$, Gelita, lot LF22703 11 , SP, Brazil); Fortigel ${ }^{\circledR}(\mathrm{LGE})$ containing $97.38 \pm 0.74 \%{ }^{[18]}$ of proteins (MW of $3 \mathrm{kDa}$, Gelita, lot LF897757 09, SP, Brazil) were employed as biopolymers. Commercial sunflower oil (Cargill Agrícola, SP, Brazil); calcium chloride $\left(\mathrm{CaCl}_{2}\right)$ (Dinâmica, batch 44034, SP, Brazil); sodium hydroxide (NaOH) (Dinâmica, lot 53187, SP, Brazil); hydrochloric acid $(\mathrm{HCl})$ (Merck, SP, Brazil); concentrated sulfuric acid $\left(\mathrm{H}_{2} \mathrm{SO}_{4}\right)$ (Synth, Diadema, SP, Brazil); Pepsin (3180 U/mg of protein), swine pancreatin (3 X USP unit of enzyme activity) and mucin (Sigma-Aldrich, MO, USA). All reagents used were of analytical grade. Deionized water were used to prepare the solutions.

\subsection{Characterization of biopolymers}

\subsubsection{Molar weight (MW) distribution of HGE and hydrolysates}

HGE and the hydrolysates were mixed $(1 \%, w / v)$ with a buffer (Tris-HCl $62.5 \mathrm{mM}$; SDS $2 \%$; glycerol 20\%; $\beta$-mercaptoethanol $5 \%$ and bromophenol blue, $\mathrm{pH} 6.8$ ) and boiled for $5 \mathrm{~min}$. Polyacrylamide gel (SDS-PAGE-Glycine, $0.75 \mathrm{~mm}$ ) was prepared according to Laemmli ${ }^{[19]}$, with $4 \%$ packaging and $7 \%$ - separation gels. $4 \mu \mathrm{L}$ of HGE and $10 \mu \mathrm{L}$ of hydrolysates solution were poured into the gel wells. The voltage was adjusted to $70 \mathrm{~V}$ and the electrophoresis (MiniProtean II Bio Rad equipment, CA, USA) was performed for 2 hours at $23 \pm 2{ }^{\circ} \mathrm{C}$. Coomassie brilliant blue G-250 solution $(0.1 \%)$ was used to stain the protein. To eliminate the background color, it was placed in a bleached solution (methanol (40\%, v/v) and acetic acid (10\%, v/v)). The MW distribution of the LGE hydrolysate was also determined by using the polyacrylamide-SDS-Tricine gel ( $1.5 \mathrm{~mm}, 4 \%$ -packaging, $16.5 \%$-separation gels), according to Schägger and von Jagow ${ }^{[20]}$. The use of tricine allows better resolution for small proteins (less than $14 \mathrm{kDa}$ ). $20 \mu \mathrm{L}$ of sample was applied to the gel channels and the run was carried out at $85 \mathrm{~V}$, at room temperature $\left(23 \pm 2^{\circ} \mathrm{C}\right)$. Proteins with MW ranging from 37 to $250 \mathrm{kDa}$ (Code: 161-0375) and 1.42 to $26.62 \mathrm{kDa}$ (Code: 161-0326) from Bio-Rad Laboratories (CA, USA) were used as standard.

\subsubsection{Identification of working pH for protein adsorption}

The zeta potential (ZP) of biopolymeric solutions (SA, HGE, MGE, LGE) and SA:HGE mixtures and at 0.1\% $\mathrm{w} / \mathrm{w}$ was measured as a function of $\mathrm{pH}(3.0-7.0)$ using a Zetasizer (Nano ZS, Malvern Instrument Ltd., UK) at $25{ }^{\circ} \mathrm{C}$. The solution $\mathrm{pH}$ was adjusted by dropwising $\mathrm{HCl}$ or $\mathrm{NaOH}(0.1 \mathrm{~N})$. Volumetric ratios of SA:HGE mixtures were prepared (1:1 to $1: 10)$, maintaining the final volume constant in $30 \mathrm{~mL}$. The mixtures were kept under stirring in a tube shaker (AP 22, Phoenix, SP, Brazil) for $1 \mathrm{~h}$. After determining the $\mathrm{ZP}$, the remaining mixtures were kept at rest for $12 \mathrm{~h}$ and subsequently photographed. Since greater amount of precipitated coacervate was observed for $\mathrm{pH}$ 3.0 , only $\mathrm{pH} 3.0$ was used for the continuity of the work. All systems and measurements were realized in triplicate.

\subsection{Production of microparticles by ionic gelation}

Microparticles were obtained following procedures described by Nogueira et al. ${ }^{[10]}$, by using an emulsion produced with $1.65 \% \mathrm{w} / \mathrm{w}$ of sunflower oil and SA solution $(2 \%, \mathrm{w} / \mathrm{w})$ through homogenization at $14.000 \mathrm{rpm}$ for $3 \mathrm{~min}$ (Ultra turrax ${ }^{\circledR}$, IKA Works, RJ, Brazil). The emulsion ( $\mathrm{pH}$ - 3.0) was atomized in a solution of $\mathrm{CaCl}_{2}(2 \%, \mathrm{w} / \mathrm{v})$ with the aid of a peristaltic pump, flow rate $556 \mathrm{~mL} / \mathrm{h}$, a double fluid atomizer nozzle, $\varnothing 1 \mathrm{~mm}$, air pressure of $0.125 \mathrm{kgf} / \mathrm{cm}^{2}$.

\subsection{Protein adsorption by electrostatic interaction}

$100 \mathrm{~g}$ of moist microparticles were added to $200 \mathrm{~mL}$ of protein solution ( $\mathrm{pH} 3.0$ ) at $45^{\circ} \mathrm{C}$ for 15 min under stirring. The final volume was kept constant, and the amounts of HGE or hydrolysates was adjusted to obtain 1, 2, 4, 6, 8 and $10 \% \mathrm{w} / \mathrm{v}$ of protein in the solution. Then, the microparticles were sieved (mesh $53 \mu \mathrm{m}$ ) and three times washed with acidified water at $\mathrm{pH} 3.0$ with $\mathrm{HCl} 0.1 \mathrm{~N}$. Three repetitions were performed.

\subsection{Microparticles characterization}

\subsubsection{Protein, moisture content and average size of microparticles}

The microparticles were characterized in terms of protein and moisture content, following the methodologies described by $\mathrm{AOAC}^{[18]}$ in triplicate. Total nitrogen content $(\mathrm{N})$ was obtained by the Kjeldahl method using a conversion factor of the $\mathrm{N} x$ 5.55. The moisture content was determined by oven drying at $105^{\circ} \mathrm{C}$ up to constant weight. The average size of the microparticles $\left(\mathrm{D}_{0.5}\right)$ was determined in a Mastersizer 2000 equipment (Malvern, Worcestershire, UK), using acidified water at $\mathrm{pH} 3.0$ as a dispersant. Size determinations were performed in triplicate.

\subsubsection{Optical microscopies of sectioned microparticles}

Newly processed wet microparticles were soaked in a polymerizable historesin at $40{ }^{\circ} \mathrm{C}$ for 2 hours (LEICA HISTORESIN Embedding kit 7022 18500, Solms, Germany). The microparticles embedded in historesin were sectioned in a LEICA RM2245 microtome (LKB, Ultrotome III 8,800 , Solms, Germany) using glass knives. The sections of approximately 2-3 $\mu \mathrm{m}$ were placed on glass slides and subjected to the following histochemical methods ${ }^{[1]}$ : 
a) To check the presence of polysaccharides, the slides were immersed in $1 \%$ Schiff's periodic acid (PAS) for $20 \mathrm{~min}$, washed for $15 \mathrm{~min}$ in running water, immersed again in PAS for another $20 \mathrm{~min}$ and, finally, washed for $5 \mathrm{~min}$ in running water ${ }^{[21]}$ and, after:

b) To identify the specific presence of proteins, the slides were immersed in a $0.5 \%$ Coomassie brilliant blue aqueous solution G-250 for 60 min and then washed in Clark's solution (acetic acid and absolute alcohol (1:3)) for 5 min repeatedly. The slides were dried at room temperature and the historesin sections were covered using histological mounting medium or immersion oil for observation and photomicrographic documentation under the NIKON light microscope, Eclipse E 800 (Tokyo, Japan).

\subsubsection{In vitro gastrointestinal evaluation of microparticles with} protein coating

Freshly processed moist microparticles coated with protein solution (HGE, MGE and LGE at $10 \%$, w/w) were employed to in vitro gastrointestinal (GIA) test. Artificial gastric juice (SGA) with $\mathrm{pH} 2.0$ was prepared with the following composition: $1.12 \mathrm{~g} / \mathrm{L} \mathrm{KCl}, 2 \mathrm{~g} / \mathrm{L} \mathrm{NaCl}, 0.11$ $\mathrm{g} / \mathrm{L} \mathrm{CaCl}_{2}, 0.4 \mathrm{~g} / \mathrm{L} \mathrm{KH}_{2} \mathrm{PO}_{4}, 3.5 \mathrm{~g} / \mathrm{L}$ mucin and $0.26 \mathrm{~g} / \mathrm{L}$ of pepsin. For $\mathrm{pH}$ adjustment, $\mathrm{HCl}(0.1 \mathrm{~N})$ was used ${ }^{[22]}$.

The GIA was carried out in $50 \mathrm{~mL}$ glass tubes, using 3 grams of moist microparticles and $30 \mathrm{~mL}$ of SGA. The samples were incubated at $37{ }^{\circ} \mathrm{C}$, in a water bath with agitation at $150 \mathrm{rpm}$, for $2 \mathrm{~h}$. After this time, the samples were centrifuged for $10 \mathrm{~min}$ at $17.000 \mathrm{rpm}$ (RC-5C Sorvall Instruments, Wilmington, USA), and a small portion analysed for protein solubility and morphology. Afterwards, the $\mathrm{pH}$ of the media was adjusted to 7.0 with a $20 \% \mathrm{NaHCO}_{3}$ solution, and pancreatin solution $(1.95 \mathrm{~g} / \mathrm{L})$ was added for simulation of intestinal conditions. The samples were then re-incubated for an additional 5 and 17 hours, with morphological observation and determination of the solubilized protein in each period. The morphology of the samples was observed in an optical microscope (JENAVAL, Tokyo, Japan) with objectives of $12.5,25,40$ and $60 \mathrm{x}$, and optovar of $0.8,1.0$ and $1.25 \mathrm{x}$. The images were captured using the EDN-2-Microscopy Image Processing System software.

The sample removed for protein quantification and morphology observation were placed in a water bath with ice for $15 \mathrm{~min}$, centrifuged for $20 \mathrm{~min}$ at $15.000 \mathrm{rpm}$ (RC-5C Sorvall Instruments, Wilmington, USA). The protein content was quantified in the supernatant by Kjeldahl[ ${ }^{[18]}$ using $\mathrm{N}$ $\mathrm{x} 5.55$, minus the nitrogen amount determined in SGA (blank). The solubilized protein content in relation to the initial protein present in the microparticles is expressed in percentage and on a dry basis. The protein solubility measurement was performed in three independent tests, each test being performed in triplicate.

\subsubsection{Statistical analysis}

The results were analyzed using the SAS 9.2 statistical program to determine the analysis of variance and the comparison between the means was made by the Tukey test with a $95 \%$ confidence level. The number of repetitions was specified in each assessment.

\section{Results and Discussion}

\subsection{Characterization of biopolymers}

\subsubsection{Molar weight (MW) distribution}

The SDS-PAGE-Glycine for HGE, MGE and LGE is shown in Figure 1a. HGE presented many protein bands distinguishable in molar weights close to $\sim 37, \sim 50$, between
M HGE MGE LGE

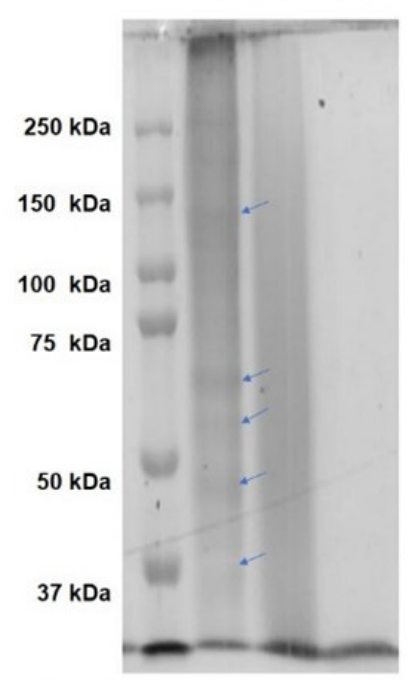

a. Polyacrylamide gel- SDS- Glycine

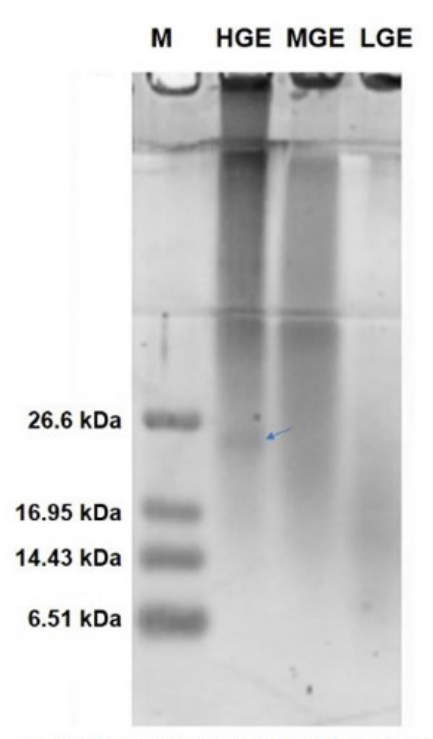

b. Polyacrylamide gel- SDS- Tricine

Figure 1. Polyacrylamide gel-SDS-PAGE electrophoresis patterns. The first lane shows the marker sample (M) with different range of molecular weights. (a) gel with Glycine and standard size markers from 37 to $250 \mathrm{kDa}$; (b) gel with Tricine and standards size markers from 6.51 to 26.6 kDa. HGE: Gelatin; MGE: Collagel $\Re$; LGE: Fortigel ${ }^{\circ}$. 
50 and 75, between 100 and 150, 250 and also protein fractions with MW greater than $250 \mathrm{kDa}$. The diffuse pattern of MGE bands, typical of a hydrolysed product, presented MW between 37 and $150 \mathrm{kDa}$. LGE could not be detected in the SDS-Glycine polyacrylamide gel.

Then, polyacrylamide-SDS-Tricine gel (Figure 1b), with higher density and less porosity, was used to identify the protein fractions of the hydrolysates. The protein patterns adopted for this gel had MW ranging from 1.42 to $26.62 \mathrm{kDa}$. The intermediate hydrolysate MGE still presented a diffuse pattern, but it was allowed to identify some fractions with MW of $\sim 16.9 \mathrm{kDa}$ and higher. Compared to the standard mixture, MGE showed peptide fractions higher than $16.9 \mathrm{kDa}$. For LGE, which is an intensely hydrolysed material and with a diffuse pattern in electrophoresis, peptide fractions with MW between 6.5 and $26.6 \mathrm{kDa}$ can be identified, as specified by the manufacturer. HGE presented MW greater than $16.9 \mathrm{kDa}$ and protein material present in the stacking gel that was unable to migrate to the separation gel due to its large size.

\subsubsection{Determination of the zeta potential of polymers}

The $\mathrm{SA}$ solution showed negative $\mathrm{ZP}$ over the entire $\mathrm{pH}$ range studied, ranging from $-33.1 \mathrm{mV}$ at $\mathrm{pH} 3.0$ to $-66.7 \mathrm{mV}$ at $\mathrm{pH} 7.0$ (Figure 2). The HGE solution showed positive $\mathrm{ZP}$ from $+21.6 \mathrm{mV}$ at $\mathrm{pH} 3.0$ to $+3.0 \mathrm{mV}$ at $\mathrm{pH} 7.0$, which confirms the type A HGE, which possesses IEP between $\mathrm{pH} 7.0$ and $9.0^{[12]}$. The ZP values of the MGE and LGE varied between $+13.3 \mathrm{mV}(\mathrm{pH} 3.0)$ to $-12.3 \mathrm{mV}(\mathrm{pH} 7.0)$ and between $+6.6 \mathrm{mV}$ (pH 3.0) to $-12.8 \mathrm{mV}(\mathrm{pH} 7.0$ ), respectively. The respective IEP were identified at $\mathrm{pH} 4.5$ for LGE and at $\mathrm{pH} 4.0$ for MGE.

The $\mathrm{ZP}$ along $\mathrm{pH}$ allowed the determination of the amount of net charge in solution of the polysaccharide and proteins, thus indicating the $\mathrm{pH}$ range that satisfies the condition $\mathrm{pKa}$ $<\mathrm{pH}<$ IEP. EI could occur throughout the studied range (pH 3.0 to $\mathrm{pH}$ 7.0) for HGE, but below to the IEP of LGE
(pH 4.0) and MGE (pH 4.5). Then, $\mathrm{pH} 3.0 ; 3.5$ and 4.0 and different volumetric mixtures between SA: HGE solutions were considered for adsorption study. EI between SA and HGE were reported at $\mathrm{pH} 3.5^{[23]}$ and at $\mathrm{pH} 4.0^{[24]}$ and with whey proteins (IEP $\sim 5$ ) were also previously performed at $\mathrm{pH}$ values 3.50 and $3.75^{[10]}$.

\subsection{Identification of working $\mathrm{pH}$ for protein adsorption}

The adsorption of proteins onto alginate microparticles is expected to be driven by electrostatic interation (EI), but the exact determination of the surface charges of the microparticles can not be properly performed due to their large sizes, which present a very rapid sedimentation in the measurement cells.

The formation of alginate particles is accompanished by the replacement of monovalent sodium $\left(\mathrm{Na}^{+1}\right)$ íons from SA by the divalent calcium $\left(\mathrm{Ca}^{2+}\right)$ ones, so that the particle surface will have less negative charge available for interaction with the protein solutions, in relation to the SA solution.

Measurements were realized for very small particles. Opanasopit et al. ${ }^{[25]}$ by using pressure nozzles to produce particles $(<10 \mu \mathrm{m})$ found that the pectin microparticles showed about one third $(-10.4 \mathrm{mV})$ of the surface charge in relation to the value of the $\mathrm{ZP}$ corresponding to the pectin solution. In another work, ZP values for SA particles, sized around $150 \mu \mathrm{m}$, were determined using the diffusion of electrolytic solutions of known charge. The authors observed that the charge of the SA microparticles was $-0.68 \pm 0.08$ $\mathrm{mV}$ at $\mathrm{pH} 4.0$ which allows the adsorption of a positive charges protein ${ }^{[26]}$.

Then, aiming to preliminarly find suitable conditions to allow the adsorption takes place, mixture of protein solutions and SA solutions were realized in a more limited range of $\mathrm{pH}(3.0$ to 4.0$)$. The mixture of a diluted solution of positively charged HGE and an anionic polyelectrolyte can lead to phase separation, with one of the phases rich in complexed biopolymers and a second very diluted

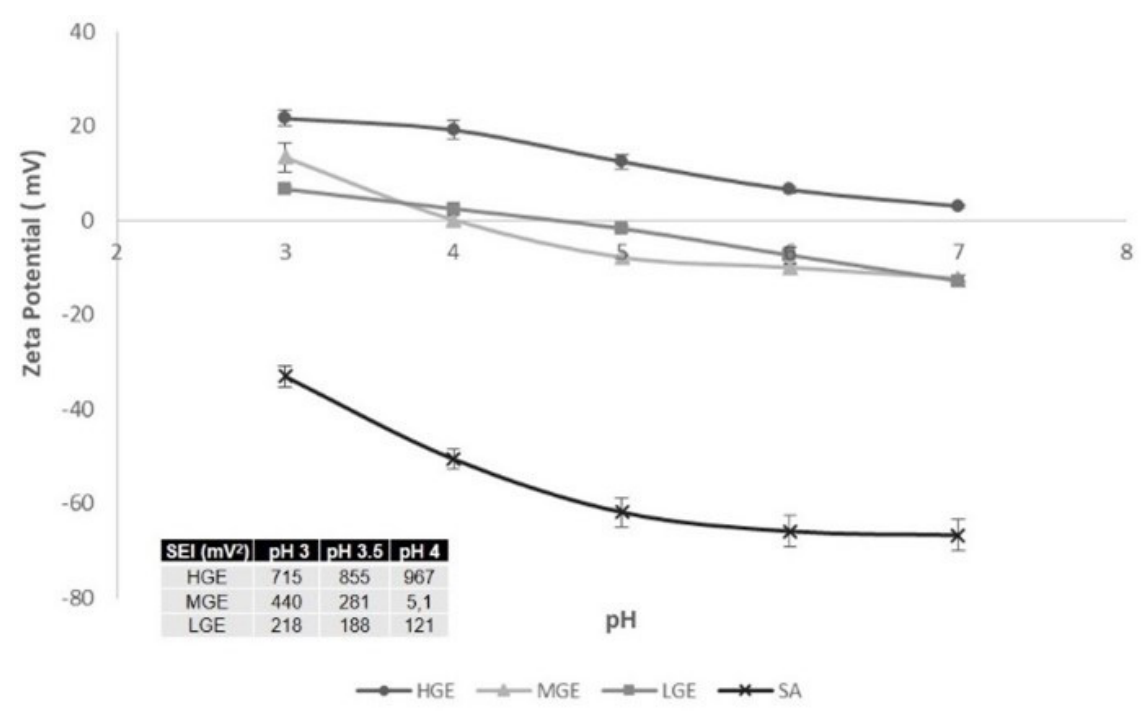

Figure 2. Zeta potential of polymers solutions against $\mathrm{pH}$ (from 3.0 to 7.0). SA: Sodium alginate; HGE: Gelatin; MGE: Collagel®; LGE: Fortigel®. 
phase, practically free of such hydrocolloids ${ }^{[16]}$. The charge stoichiometry between the biopolymers depends on the ratio between polyelectrolytes and $\mathrm{pH}$. Besides, the concentration of biopolymers is crucial since it strongly has influence on the unfolding and mobility of the molecules ${ }^{[27]}$.

Figure 3 shows different volumetric proportions ( $1: 1$ to $1: 10)$ between SA and HGE diluted solutions $(0.1 \%, \mathrm{w} / \mathrm{w})$, at $\mathrm{pH} 3.0, \mathrm{pH} 3.5$, and $\mathrm{pH} 4.0$, keeping constant the temperature. The $\mathrm{ZP}(\mathrm{mV})$ of Figure 3 indicates the surplus of negative charge increases with the increasing of $\mathrm{pH}$. The behaviour is expected since the - $\mathrm{COOH}$ groups of SA became deprotonated by increasing the $\mathrm{pH}$. The requirement of positive charge

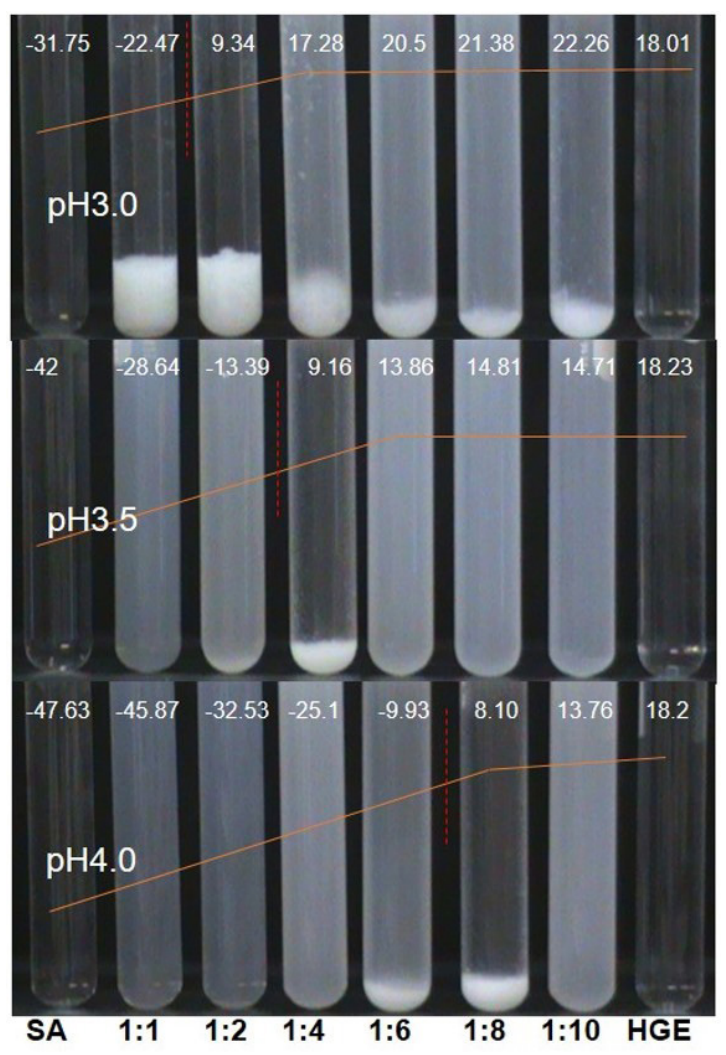

Figure 3. Visual aspect and zeta potential $(\mathrm{mV})$ of mixtures at different ratios $(1: 1 ; 1: 2 ; 1: 4 ; 1: 6 ; 1: 8$ e $1: 10)$ between SA:HGE solutions at $\mathrm{pH} 3.0, \mathrm{pH} 3.5$ and $\mathrm{pH} 4.0$. The line illustrate ZP variation and the vertical line, the turning point of $\mathrm{pH}$ from negative to positive surface charge. SA: Sodium alginate; HGE: Gelatin. to counterbalance the excess of negative charges of the SA raised from 1 part of $\mathrm{HGE}$ at $\mathrm{pH} 3.0$, to 6 part of HGE at $\mathrm{pH}$ 4.0. The same proportion was found by Bastos et al. ${ }^{[24]}$ at $\mathrm{pH} 4.0$, evaluated by turbidimetry. Moreover, as shown by the schematic line traced to represent the zeta potential, it is observed an increase of $\mathrm{ZP}$ with the proportion of HGE, and a saturation of charges is reached right after the turning point (ZP is constant and identical to the HGE solution), with exception of $\mathrm{pH}$ 4.0. This condition of unchanged $\mathrm{ZP}$ and followed by the turbidity development of the sobrenadant indicates that no more interaction occurs.

The turning $\mathrm{pH}$ was accompanied by the formation of a precipitated mass of coacervates with transparent supernatant phase. The visual comparison of the coacervate formed at $\mathrm{pHs} 3.0,3.5$ and 4.0 shows that greater volumes were formed for systems at $\mathrm{pH}$ 3.0. This could be consequence of the weaker attraction between HGE and SA at the lowest $\mathrm{pH}$, as shown by the strength of the electrostatic interaction (SEI) values. The SEI was calculated between oppositely charged polyelectrolytes ${ }^{[28,29]}$ in $\mathrm{pH} 3.0,3.5$ and 4.0 and it is shown inside of Figure 2. The highest SEI values indicate strongest attractions between opposite biopolymers. The $\mathrm{SEI}$ increased with the $\mathrm{pH}$ for HGE, keeping greater values than for MGE and LGE. Conversely, SEI values for both hydrolisates reduced with increased $\mathrm{pH}$. Therefore, the $\mathrm{pH} 3.0$ was chosen for the protein adsorption in the microparticles and the subsequent evaluations.

\subsection{Microparticles characterization}

\subsubsection{Protein, moisture content and average size of microparticles}

The amount of protein detected in the microparticles after their immersion in protein solution (Table 1) indicates that interactions occurred between carboxyl groups of SA and positively charged amino groups of the proteins. Contrarily to that observed for solutions, where a "saturation point" was detected by stabilization of ZP values, the amount of protein adsorbed on the particles increased with protein content in solution, regardless of the type of protein used, indicating that, in addition to the protein-polysaccharide EI interaction, protein-protein EI may have occurred, contributing to the high protein adsorption. A similar effect was observed previously ${ }^{[30]}$ and also when whey protein and ovalbumin or a mixture of proteins were adsorbed on $\operatorname{IGEL}^{[9,26]}$. Different surface forces can be associated with interactions between polyelectrolytes including van der Waals forces, hydrogen bonds, and, in particular, electrostatic and hydrophobic

Table 1. Protein and moisture content (\%) of IGEL microparticles after protein coating as a function of different concentrations of protein in solution $(\%, w / w)$.

\begin{tabular}{|c|c|c|c|c|c|c|}
\hline \multirow{2}{*}{$\begin{array}{c}\text { Protein in solution } \\
\qquad(\%)\end{array}$} & \multicolumn{3}{|c|}{ Protein adsorbed (\%) } & \multicolumn{3}{|c|}{ Moisture content (\%) } \\
\hline & HGE & MGE & LGE & HGE & MGE & LGE \\
\hline 1 & $26.5 \pm 0.6^{\text {Еа* }}$ & $25.1 \pm 0.5^{\mathrm{Eb}}$ & $16.3 \pm 0.4^{\mathrm{Ec}}$ & $86.9 \pm 1.0^{\mathrm{Ac}}$ & $89.8 \pm 0.6^{\mathrm{Ab}}$ & $91.6 \pm 0.8^{\mathrm{Aa}}$ \\
\hline 2 & $35.2 \pm 2.0^{\mathrm{Da}}$ & $29.8 \pm 0.7^{\mathrm{Db}}$ & $19.6 \pm 0.4^{\mathrm{Dc}}$ & $86.0 \pm 0.8^{\mathrm{Ac}}$ & $87.2 \pm 0.9^{\mathrm{Bb}}$ & $88.8 \pm 0.8^{\mathrm{BCa}}$ \\
\hline 4 & $38.9 \pm 0.7^{\mathrm{Ca}}$ & $32.6 \pm 0.8^{\mathrm{Cb}}$ & $21.2 \pm 0.9^{\mathrm{Cc}}$ & $82.6 \pm 0.6^{\mathrm{Bc}}$ & $86.1 \pm 1.4^{\mathrm{BCb}}$ & $88.8 \pm 0.2^{\mathrm{BCa}}$ \\
\hline 6 & $44.0 \pm 2.1^{\mathrm{Ba}}$ & $40.1 \pm 0.6^{\mathrm{Bb}}$ & $24.7 \pm 0.6^{\mathrm{Bc}}$ & $78.4 \pm 1.0^{\mathrm{Cc}}$ & $83.8 \pm 0.8^{\mathrm{Cb}}$ & $89.1 \pm 0.5^{\mathrm{BCa}}$ \\
\hline 8 & $44.4 \pm 1.4^{\mathrm{Ba}}$ & $40.8 \pm 1.4^{\mathrm{ABb}}$ & $24.2 \pm 1.0^{\mathrm{Bc}}$ & $78.0 \pm 1.1^{\mathrm{CDc}}$ & $85.4 \pm 0.9^{\mathrm{Db}}$ & $89.4 \pm 0.7^{\mathrm{Ba}}$ \\
\hline 10 & $47.3 \pm 1.1^{\mathrm{Aa}}$ & $41.4 \pm 0.5^{\mathrm{Ab}}$ & $29.3 \pm 0.5^{\mathrm{Ac}}$ & $76.6 \pm 2.2^{\mathrm{Dc}}$ & $81.1 \pm 0.9^{\mathrm{Eb}}$ & $88.2 \pm 0.5^{\mathrm{Ca}}$ \\
\hline
\end{tabular}

*Averages followed by the same letters (upper cases on the same columns and lower cases on the same lines) did not differ according to Tukey's test $(p>0.05)$. IGEL: Ionic gelation; HGE: Gelatin; MGE: Collagel $\AA$; LGE: Fortigel ${ }^{\circledR}$. 
interactions ${ }^{[31]}$. Molina-Ortiz et al. ${ }^{[32]}$ studied interactions between carrageenan and soy protein and showed that the complexes were formed at both, high and low $\mathrm{pH}$ values. According to the authors, EI dominate at low $\mathrm{pH}$ whereas hydrophobic interactions are the dominant interactions in complexes at high $\mathrm{pH}$.

Significant differences in adsorption between the three protein materials were observed. The adsorbed amount increases with MW. As can be seen in Table 1, in the highest amount of protein in solution (10\%), values of 47.3, 41.4 and $29.3 \%$ (w/w, dry basis) of protein adsorbed on the microparticles were found when HGE, MGE and LGE were used. Similar behavior was obtained for spray-dried microparticles of SA crosslinked with epichlorohydrin. The adsorption of lysozyme $(14.3 \mathrm{kDa})$ and chymotrypsinogen $(25.6 \mathrm{kDa})$ reached very high protein amounts corresponding to 1880 and $3034 \mathrm{mg}$ of protein/g of SA respectively ${ }^{[33]}$. The values of ZP (Figure 2) corroborate the electrostatic contribution for adsorption, with the growing order: HGE $>$ MGE $>$ LGE. In addition, the ZP presented by LGE is significantly lower $(+6.6 \mathrm{mV})$ than the ZP observed for $\mathrm{HGE}$ and MGE, +21.6 and $+13.3 \mathrm{mV}$, respectively.

An adsorption study with human blood proteins indicated that proteins larger than albumin $(66.3 \mathrm{kDa})$ could occupy multiple layers in the adsorption process, while smaller proteins adsorbed completely or partially as a monolayer ${ }^{[17]}$. In another study ${ }^{[34]}$, protein adsorption at the equilibrium was: albumin $(66.3 \mathrm{kDa})<$ fibrinogen $(340 \mathrm{kDa})<$ fibronectin (450 kDa).

Besides size and charge density, many other factors would be included in the adsorption of polyelectrolytes on charged surfaces as non-planar surfaces, porosity of microparticles, chemical structure, protein conformation, chain length, type of charge, charge density and charge distribution ${ }^{[35]}$. Another recent review mentioned additional properties of the polymers, such as architecture, density and wettability, chemical and structure's properties, functional groups, interfacial free energy and conformational flexibility among others ${ }^{[36]}$.

The protein adsorption changed the moisture content of the particles (Table 1). The higher the amount of adsorbed protein, the lower moisture content of the microparticles. Also, the moisture content of particles increased with decreasing the MW of the coating material. The IGEL moist microparticles without coating showed average sizes $\left(\mathrm{D}_{0.5}\right)$ varying between $83.4 \pm 16.6$ and $105.2 \pm 34.0 \mu \mathrm{m}$. Protein adsorption, irrespective of whether HGE, MGE or LGE, produced an increase in the average size of the IGEL microparticles (Table 2). However, the HGE was the only that presented variation in sizes with the protein bulk concentration.

Table 2. Average size $\left(D_{0.5}\right)$ of microparticles after protein adsorption $(\mu \mathrm{m})$ as a function of the amount of protein in solution $(\%, \mathrm{w} / \mathrm{w})$

\begin{tabular}{cccc}
\hline \multirow{2}{*}{$\begin{array}{c}\text { Protein in } \\
\text { solution (\%) }\end{array}$} & \multicolumn{3}{c}{ Average size $\left(\mathbf{D}_{\mathbf{0 . 5}} \boldsymbol{\mu}\right.$, $)$} \\
\cline { 2 - 4 } & IGEL + HGE & IGEL + MGE & IGEL + LGE \\
\hline $\mathbf{1}$ & $122.9 \pm 13.1^{\mathrm{Ba} *}$ & $132.6 \pm 7.8^{\mathrm{Aa}}$ & $139.8 \pm 9.7^{\mathrm{Aa}}$ \\
$\mathbf{2}$ & $137.1 \pm 11.3^{\mathrm{Ba}}$ & $143.1 \pm 6.4^{\mathrm{Aa}}$ & $117.8 \pm 5.9^{\mathrm{Aa}}$ \\
$\mathbf{4}$ & $147.7 \pm 31.3^{\mathrm{Aba}}$ & $135.0 \pm 33.9^{\mathrm{Aa}}$ & $134.9 \pm 22.7^{\mathrm{Aa}}$ \\
$\mathbf{6}$ & $164.9 \pm 20.2^{\mathrm{Aba}}$ & $110.1 \pm 4.0^{\mathrm{Ab}}$ & $132.5 \pm 13.4^{\mathrm{Ab}}$ \\
$\mathbf{8}$ & $158.3 \pm 15.3^{\mathrm{Aba}}$ & $111.2 \pm 6.1^{\mathrm{Ab}}$ & $116.3 \pm 6.3^{\mathrm{Ab}}$ \\
$\mathbf{1 0}$ & $200.2 \pm 53.5^{\mathrm{Aa}}$ & $128.9 \pm 22.9^{\mathrm{Aa}}$ & $120.5 \pm 16.6^{\mathrm{Aa}}$ \\
\hline
\end{tabular}

*Averages followed by the same letters (upper cases on the same columns and lower cases on the same lines) did not differ according to Tukey's test $(p>0.05)$. IGEL: Ionic gelation; HGE: Gelatin; MGE: Collagel®; LGE: Fortigel ${ }^{\circledR}$.
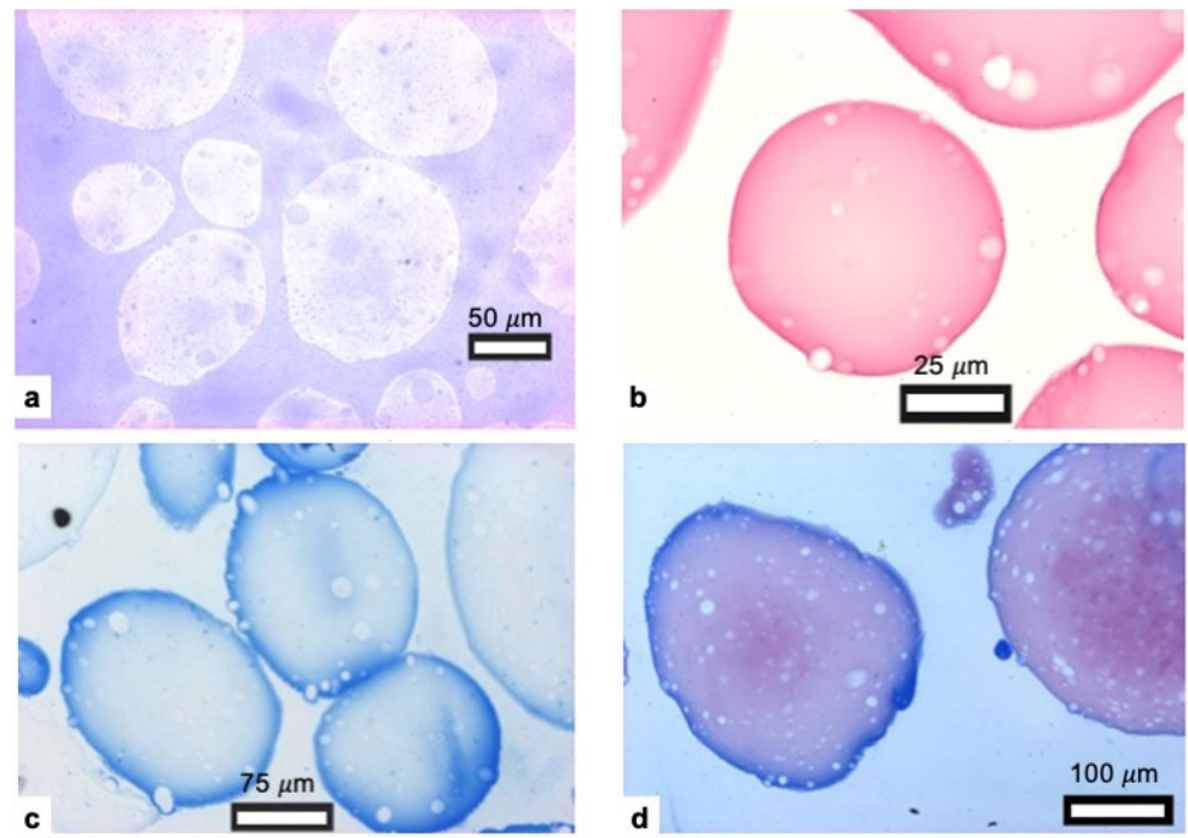

Figure 4. Optical microscopy of sectioned IGEL microparticles. Top line: uncoated microparticles stained with Coomassie brilliant blue (CB) (a), and Schiff's periodic acid (PAS) (b); Bottom line: microparticles coated with the protein stained with CB (c) and with PAS and then with $\mathrm{CB}(\mathrm{d})$. 


\subsubsection{Optical microscopies of sectioned microparticles}

Figure 4 shows micrographs of microparticles embedded in the polymerized material and later sliced into the microtome, colored with specific dyes for carbohydrates and proteins. Uncoated IGEL microparticles as expected did not show Coomassie brilliant blue staining by the absence of protein coating material (Figure 4.a).

In Figure 4.b, the same particles stained with the PAS acquired a pink color, typical for the PAS-carbohydrate interaction. In Figure 4.c, IGEL microparticles coated with protein showed a blue halo on the perimeter of the microparticles corresponding to the layer of protein adsorbed on the microparticles and oil vesicles without staining. Figure 4.d shows particles containing protein first stained with PAS and then with Coomassie where the interior of the particles is pink and the perimeter shows a blue halo, which means a strong indication of the adsorbed protein.

3.3.3 In vitro gastrointestinal evaluation of microparticles with protein coating

The solubility of proteins adsorbed onto microparticles is shown in Table 3. It was observed that 39.1, 41.8 and $49.0 \%(\mathrm{w} / \mathrm{w})$ of total protein present in the microparticles

Table 3. Protein release (\%) during gastrointestinal in vitro evaluation (IGEL microparticles $+10 \%$ of protein in solution).

\begin{tabular}{|c|c|c|c|}
\hline \multirow{3}{*}{ Protein } & \multicolumn{3}{|c|}{ Digestion time } \\
\hline & \multirow{2}{*}{$\begin{array}{c}\text { Simulated gastric } \\
\text { conditions pepsin, } \\
\text { pH } 2\end{array}$} & \multicolumn{2}{|c|}{$\begin{array}{c}\text { Simulated intestinal conditions } \\
\text { pancreatin, pH } 7\end{array}$} \\
\hline & & $7 \mathrm{~h}$ & $24 h$ \\
\hline HGE & $39.1 \pm 5.3^{\text {Ac* }}$ & $81.3 \pm 2.5^{\mathrm{Bb}}$ & $96.5 \pm 3.5^{\mathrm{Aa}}$ \\
\hline MGE & $41.8 \pm 4.5^{\mathrm{Ac}}$ & $61.5 \pm 6.5^{\mathrm{Cb}}$ & $82.3 \pm 6.6^{\mathrm{Ba}}$ \\
\hline LGE & $49.0 \pm 1.9^{\mathrm{Ab}}$ & $95.2 \pm 3.9^{\mathrm{Aa}}$ & $96.1 \pm 3.9^{\mathrm{Aa}}$ \\
\hline
\end{tabular}

*Averages followed by the same letters (upper cases on the same columns and lower cases on the same lines) did not differ according to Tukey's test $(\mathrm{p}>0.05)$. IGEL: Ionic gelation; HGE: Gelatin; MGE: Collagel ${ }^{\circledR}$; LGE: Fortigel ${ }^{\circledR}$. coated with HGE, MGE and LGE, respectively, solubilized after $2 \mathrm{~h}$ in artificial gastric fluid (Table 3 ), showing that all coatings were susceptible to gastric conditions. Despite the high protein solubility, the microparticles were still intact, spherical and dense (Figure 5). The coating of microparticles with HGE and its hydrolysates was inefficient compared to results observed when whey protein was adsorbed onto microparticles IGEL ${ }^{[9]}$. These authors observed a low solubility of the adsorbed layer of whey protein (WPC) under simulated gastric conditions $\left(\mathrm{pH} 3.0,2 \mathrm{~h}, 37^{\circ} \mathrm{C}\right)$. The low susceptibility of WPC to pepsin in gastric conditions was previously observed ${ }^{[37]}$.

After gastric treatment (2h) the microparticle suspensions were sequentially subjected to intestinal conditions and after 7 hours an increase in the percentage of solubility was observed, from 61.5 to $95.2 \%$ according to the coating material used (Table 3 ). The particles became more transparent reflecting the loss of the protein layer, visually more swollen, but still spherical (Figure 5). After 24 hours the protein solubility increased even more, from 82.3 to $96.5 \%$ of protein released. For microparticles containing HGE and LGE, the solubilization observed was almost total in relation to the protein initially adsorbed (Table 3). Similar behaviour was previously observed for multilayer particles produced with alginate and whey protein, $30.5 \% \mathrm{w} / \mathrm{w}$ of total nitrogen protein solubilisation occurring after $2 \mathrm{~h}$ in artificial gastric fluid; while $86.0 \% \mathrm{w} / \mathrm{w}$ of total nitrogen protein solubilisation after $5 \mathrm{~h}$ in the artificial intestinal fluid ${ }^{[10]}$. Contrasting with the results obtained in this work, in a previous study ${ }^{[16]}$, the gastroenteric resistance assessment of HGE microcapsules containing lycopene resulted in a rapid release of lycopene at $\mathrm{pH} 5.5$ and 7.0, while no lycopene was released at $\mathrm{pH} 2.0$ and 3.5.

In agreement with the results obtained here, Wang et al. ${ }^{[38]}$ stated that the HGE could be digested nearly completely into oligopeptides or amino acids, which can be easily adsorbed into the small intestine. The high digestibility and bioactivity of HGE after oral administration reported by the authors

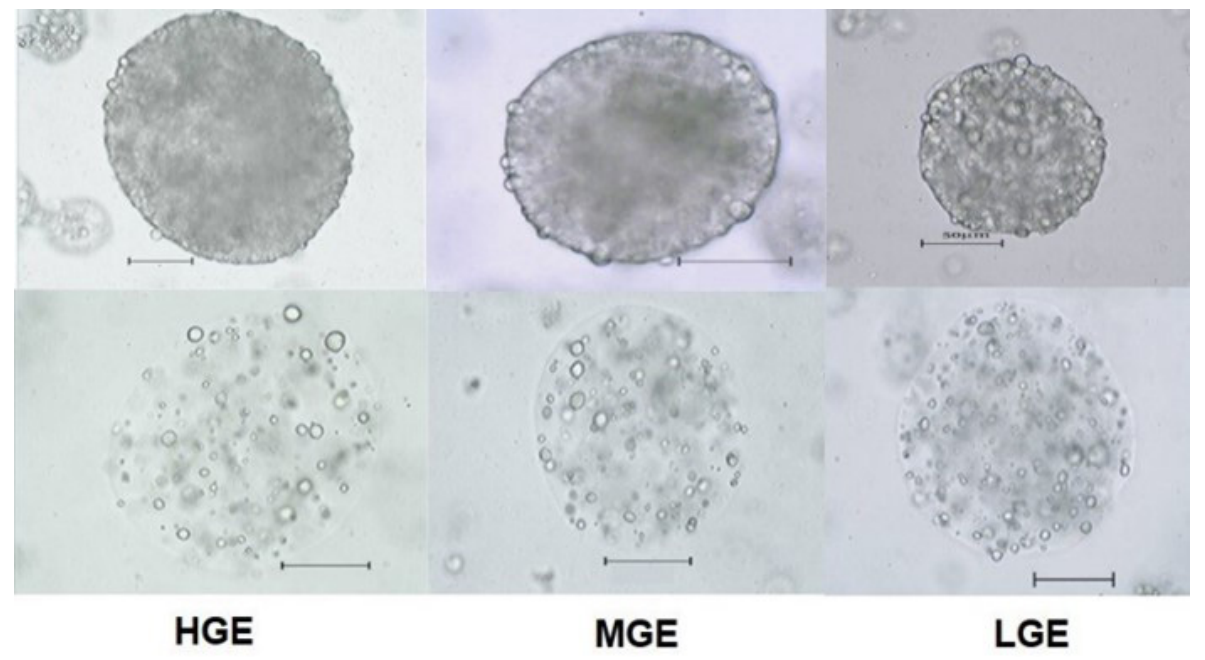

Figure 5. Optical microscopy of IGEL microparticles coated with protein submitted to in vitro gastrointestinal assay. Top line: simulated gastric conditions: $1 \mathrm{~h} \mathrm{pH}$ 2. Bottom line: simulated intestinal conditions: $24 \mathrm{~h} \mathrm{pH}$ 7. Bars represent $50 \mu \mathrm{m}$. HGE: Gelatin; MGE: Collagel ${ }^{\circledR}$; LGE: Fortigel ${ }$. 
suggest that these particles can serve to delivery bioactive compounds after consumption.

\section{Conclusions}

Appropriate range of interaction between gelatin and their hydrolisates was found to promote their adsorption on the alginate microparticles. The amount of protein adsorbed on IGEL microparticles increased with the concentration of protein in solution (10\%) and reduced with MW, with adsorptions of $\sim 47.3,41.4$ and $29.3 \%$ when HGE, MGE and LGE were obtained, respectively. The coating of fibrous protein and their hydrolisates on microparticles were poorly resistant to solubilization at gastric conditions, with $\sim 39$ to $49 \%$ protein solubilized at $\mathrm{pH} 2.0$ after $2 \mathrm{~h}$. After switching to intestinal conditions, $\mathrm{pH} 7.0$ during $5 \mathrm{~h}$, the solubility increased to $\sim 81, \sim 61$ and $\sim 95 \%$ for HGE, MGE and LGE, respectively. These results suggest that these particles can serve to delivery bioactive compounds after oral administration.

\section{Acknowledgements}

The authors are grateful to the Conselho Nacional de Desenvolvimento Científico e Tecnológico (CNPq 135122/2011-2) for the financial support.

\section{References}

1. Moura, S. C. S. R., Berling, C. L., Garcia, A. O., Queiroz, M. B., Alvim, I. D., \& Hubinger, M. D. (2019). Release of anthocyanins from the hibiscus extract encapsulated by ionic gelation and application of microparticles in jelly candy. Food Research International, 121, 542-552. http://dx.doi. org/10.1016/j.foodres.2018.12.010. PMid:31108779.

2. Liu, Q., Cai, W., Zhen, T., Ji, N., Dai, L., Xiong, L., \& Sun, Q. (2020). Preparation of debranched starch nanoparticles by ionic gelation for encapsulation of epigallocatechin gallate. International Journal of Biological Macromolecules, 161, 481-491. http://dx.doi.org/10.1016/j.ijbiomac.2020.06.070. PMid:32534085.

3. Dalponte Dallabona, I., de Lima, G. G., Cestaro, B. I., Tasso, I. S., Paiva, T. S., Laureanti, E. J. G., Jorge, L. M. M., Silva, B. J. G., Helm, C. V., Mathias, A. L., \& Jorge, R. M. M. (2020). Development of alginate beads with encapsulated jabuticaba peel and propolis extracts to achieve a new natural colorant antioxidant additive. International Journal of Biological Macromolecules, 163, 1421-1432. http://dx.doi.org/10.1016/j. ijbiomac.2020.07.256. PMid:32738324.

4. Paula, H. C. B., Oliveira, E. F., Abreu, F. O. M. S., Paula, R. C. M., Morais, S. M., \& Forte, M. M. C. (2010). ALG/Ca beads as an encapsulation agent of croton zehntneri Pax et Hoffm essential oil. Polímeros: Ciência e Tecnologia, 20(2), 112-120. http://dx.doi.org/10.1590/S0104-14282010005000019.

5. de Vos, P., Faas, M. M., Strand, B., \& Calafiore, R. (2006). Alginate-based microcapsules for immunoisolation of pancreatic islets. Biomaterials, 27(32), 5603-5617. http://dx.doi. org/10.1016/j.biomaterials.2006.07.010. PMid:16879864.

6. Hansen, L. T., Allan-Wojtas, P. M., Jin, Y.-L., \& Paulson, A. T. (2002). Survival of Ca-alginate microencapsulated Bifidobacterium spp. in milk and simulated gastrointestinal conditions. Food Microbiology, 19(1), 35-45. http://dx.doi. org/10.1006/fmic.2001.0452.
7. George, M., \& Abraham, T. E. (2006). Polyionic hydrocolloids for the intestinal delivery of protein drugs: alginate and chitosan: a review. Journal of Controlled Release, 114(1), 1-14. http:// dx.doi.org/10.1016/j.jconrel.2006.04.017. PMid:16828914.

8. Silva Carvalho, A. G., Costa Machado, M. T., Barros, H. D. F. Q., Cazarin, C. B. B., Maróstica, M. R. Jr., \& Hubinger, M. D. (2019). Anthocyanins from jussara (Euterpe edulis Martius) extract carried by calcium alginate beads pre-prepared using ionic gelation. Powder Technology, 345, 283-291. http://dx.doi. $\operatorname{org} / 10.1016 /$ j.powtec.2019.01.016.

9. Souza, F. N., Gebara, C., Ribeiro, M. C. E., Chaves, K. S., Gigante, M. L., \& Grosso, C. R. F. (2012). Production and characterization of microparticles containing pectin and whey proteins. Food Research International, 49(1), 560-566. http:// dx.doi.org/10.1016/j.foodres.2012.07.041.

10. Nogueira, G. F., Prata, A. S., \& Grosso, C. R. F. (2017). Alginate and whey protein based-multilayered particles: production, characterisation and resistance to $\mathrm{pH}$, ionic strength and artificial gastric/intestinal fluid. Journal of Microencapsulation, 34(2), 151-161. http://dx.doi.org/10.1080/02652048.2017.1310945 . PMid:28338368.

11. Li, X. Y., Chen, X. G., Cha, D. S., Park, H. J., \& Liu, C. S. (2009). Microencapsulation of a probiotic bacteria with alginategelatin and its properties. Journal of Microencapsulation, 26(4), 315-324. http://dx.doi.org/10.1080/02652040802328685. PMid:18668418.

12. Gennadios, A., Mchugh, T. H., Weller, C. L., \& Krochta, J. M. (1994). Edible coating and films based on proteins. In J. M. Krochta, E. A. Baldwin \& M. O. Nisperos-Carriedo (Eds.), Edible coatings and to improve food quality (pp. 201-277). Lancaster: Technomic Publishing.

13. Krochta, J. M., Baldwin, E. A., \& Nisperos-Carriedo, M. O. (1994). Edible coatings and films to improve food quality. Lancaster: Technomic Publ. Co. Retrieved in 2020, August 13, from https:// agris.fao.org/agris-search/search.do?recordID=US9530017

14. Gbassi, G., Vandamme, T., Ennahar, S., \& Marchioni, E. (2009). Microencapsulation of Lactobacillus plantarum spp in an alginate matrix coated with whey proteins. International Journal of Food Microbiology, 129(1), 103-105. http://dx.doi. org/10.1016/j.ijfoodmicro.2008.11.012. PMid:19059666.

15. Tolstoguzov, V. (2003). Some thermodynamic considerations in food formulation. Food Hydrocolloids, 17(1), 1-23. http:// dx.doi.org/10.1016/S0268-005X(01)00111-4.

16. Gómez-Guillén, M. C., Giménez, B., López-Caballero, M. E., $\&$ Montero, M. P. (2011). Functional and bioactive properties of collagen and gelatin from alternative sources: a review. Food Hydrocolloids, 25(8), 1813-1827. http://dx.doi.org/10.1016/j. foodhyd.2011.02.007.

17. Vogler, E. A. (2012). Protein adsorption in three dimensions. Biomaterials, 33(5), 1201-1237. http://dx.doi.org/10.1016/j. biomaterials.2011.10.059. PMid:22088888.

18. Horwitz, W., \& Latimer, G. W. (2006). Official methods of Analysis of Association of Official Analytical Chemists International. Rockville: AOAC International.

19. Laemmli, U. K. (1970). Cleavage of structural proteins during the assembly of the head of bacteriophage T4. Nature, 227(5259), 680-685. http://dx.doi.org/10.1038/227680a0. PMid:5432063.

20. Schägger, H., \& von Jagow, G. (1987). Tricine-sodium dodecyl sulfate-polyacrylamide gel electrophoresis for the separation of proteins in the range from 1 to $100 \mathrm{kDa}$. Analytical Biochemistry, 166(2), 368-379. http://dx.doi.org/10.1016/00032697(87)90587-2. PMid:2449095.

21. Sanders, B. J. (1972). Animal histology procedures of the pathological technology section of the National Cancer Institute. Bethesda: Pathological Technology Section, Laboratory of Pathology, National Cancer Institute, National Institutes of 
Health. Retrieved in 2020, August 13, from https://books. google.com.br/books?id=PZInGVWoUSsC

22. Mozzi, F., Gerbino, E., Font de Valdez, G., \& Torino, M. I. (2009). Functionality of exopolysaccharides produced by lactic acid bacteria in an in vitro gastric system. Journal of Applied Microbiology, 107(1), 56-64. http://dx.doi.org/10.1111/j.13652672.2009.04182.x. PMid:19291238.

23. Wang, L., Yang, S., Cao, J., Zhao, S., \& Wang, W. (2016). Microencapsulation of ginger volatile oil based on gelatin/sodium alginate polyelectrolyte complex. Chemical \& Pharmaceutical Bulletin, 64(1), 21-26. http://dx.doi.org/10.1248/cpb.c15-00571. PMid:26726741.

24. Bastos, L. P. H., Vicente, J., Santos, C. H. C., Carvalho, M. G., $\&$ Garcia-Rojas, E. E. (2020). Encapsulation of black pepper (Piper nigrum L.) essential oil with gelatin and sodium alginate by complex coacervation. Food Hydrocolloids, 102, 105605. http://dx.doi.org/10.1016/j.foodhyd.2019.105605.

25. Opanasopit, P., Apirakaramwong, A., Ngawhirunpat, T., Rojanarata, T., \& Ruktanonchai, U. (2008). Development and characterization of pectinate micro/nanoparticles for gene delivery. American Association of Pharmaceutical Scientists, 9(1), 67-74. http://dx.doi.org/10.1208/s12249-007-9007-7. PMid:18446463.

26. Tello, F., Falfan-Cortés, R. N., Martinez-Bustos, F., Martins da Silva, V., Hubinger, M. D., \& Grosso, C. (2015). Alginate and pectin-based particles coated with globular proteins: Production, characterization and anti-oxidative properties. Food Hydrocolloids, 43, 670-678. http://dx.doi.org/10.1016/j. foodhyd.2014.07.029.

27. Schmitt, C., Sanchez, C., Desobry-Banon, S., \& Hardy, J. (1998). Structure and technofunctional properties of proteinpolysaccharide complexes: a review. Critical Reviews in Food Science and Nutrition, 38(8), 689-753. http://dx.doi. org/10.1080/10408699891274354. PMid:9850463.

28. Weinbreck, F., Minor, M., \& Kruif, C. G. (2004). Microencapsulation of oils using whey protein/gum arabic coacervates. Journal of Microencapsulation, 21(6), 667-679. http://dx.doi. org/10.1080/02652040400008499. PMid:15762323.

29. Prata, A. S., \& Grosso, C. R. F. (2015). Influence of the oil phase on the microencapsulation by complex coacervation. Journal of the American Oil Chemists' Society, 92(7), 10631072. http://dx.doi.org/10.1007/s11746-015-2670-z.
30. Ramsden, J. J. (1995). Puzzles and paradoxes in protein adsorption. Chemical Society Reviews, 24(1), 73. http://dx.doi. org/10.1039/cs9952400073.

31. Roach, P., Farrar, D., \& Perry, C. C. (2005). Interpretation of protein adsorption: surface-induced conformational changes. Journal of the American Chemical Society, 127(22), 8168-8173. http://dx.doi.org/10.1021/ja042898o. PMid:15926845.

32. Molina-Ortiz, S. E., Puppo, M. C., \& Wagner, J. R. (2004). Relationship between structural changes and functional properties of soy protein isolates-carrageenan systems. Food Hydrocolloids, 18(6), 1045-1053. http://dx.doi.org/10.1016/j. foodhyd.2004.04.011.

33. Brassesco, M. E., Fuciños, P., Pastrana, L., \& Picó, G. (2019). Development of alginate microparticles as efficient adsorption matrix for protein recovery. Process Biochemistry, 80, 157-163. http://dx.doi.org/10.1016/j.procbio.2019.02.016.

34. Yang, J. M., Tsai, R.-Z., \& Hsu, C.-C. (2016). Protein adsorption on polyanion/polycation layer-by-layer assembled polyelectrolyte films. Colloids and Surfaces. B, Biointerfaces, 142,98-104. http://dx.doi.org/10.1016/j.colsurfb.2016.02.039. PMid:26938325.

35. Malinova, V., Freitag, R., \& Wandrey, C. (2004). Adsorption of charged macromolecules on oppositely charged porous column materials. Journal of Chromatography. A, 1036(1), 25-32. http:// dx.doi.org/10.1016/j.chroma.2003.10.087. PMid:15139410.

36. Rahmati, M., \& Mozafari, M. (2018). Protein adsorption on polymers. Materials Today Communications, 17, 527-540. http://dx.doi.org/10.1016/j.mtcomm.2018.10.024.

37. Kitabatake, N., \& Kinekawa, Y.-I. (1998). Digestibility of bovine milk whey protein and $\beta$-lactoglobulin in vitro and in vivo. Journal of Agricultural and Food Chemistry, 46(12), 4917-4923. http://dx.doi.org/10.1021/jf9710903.

38. Wang, L., Liang, Q., Chen, Q., Xu, J., Shi, Z., Wang, Z., Liu, Y., \& Ma, H. (2014). Hydrolysis kinetics and radicalscavenging activity of gelatin under simulated gastrointestinal digestion. Food Chemistry, 163, 1-5. http://dx.doi.org/10.1016/j. foodchem.2014.04.083. PMid:24912688.

Received: Mar. 05, 2021

Revised: June 21, 2021

Accepted: July 15, 2021 